Warszawskie Studia Pastoralne UKSW

Rok XI 2016 Nr 4(33)

Andreas Wollbold ${ }^{1}$

\title{
ZACHĘTA DLA DUSZPASTERSTWA ${ }^{2}$
}

Od kilku lat amerykańskie pismo dla menadżerów „Fortune” publikuje listę The Worlds 50 Leaders. Razem z szefami Amazon i Apple jedynie papież Franciszek zostaje każdego roku włączony do tego elitarnego grona. W 2016 r. czasopismo „Fortune” za najważniejsze zadanie papieża uznało pogodzenie w Kościele konserwatystów i progresistów. Adhortacja apostolska Amoris laetitia (AL) jest dokumentem wpisującym się w tę wolę jedności i wyrazem na rzecz jedności, w służbie której pozostaje urząd Piotra. Dyskusje ostatnich lat i obrady ostatnich synodów poświęconych rodzinie z 2014 i 2015 r., kazały uruchomić papieżowi proces nauczania, który mógł uczynić zadość jego wielkiemu życzeniu: osiągnięciu konsensu (por. AL 297). Oczekiwania te znalazły swój wyraz poprzez: trzeźwą i konkretną ocenę rzeczywistości (AL, rozdział 2), przedstawienie ideału Kościoła-matki wobec ludzi żyjących w sytuacjach nieregularnych, „który ich zawsze przyjmuje, troszczy się o nich z miłością i wspiera ich na drodze życia i Ewangelii” (AL 299) oraz „logikę duszpasterskiego miłosierdzia" (AL 307-312).

1 Autor (ur. 1960) jest kapłanem diecezji Trier (1984), od 2003 r. profesorem teologii pastoralnej na Uniwersytecie w Monachium. Studiował w Rzymie, Trier, Poona, Monachium i Notre Dame (USA). Licencjat w zakresie patrologii uzyskał w Rzymie (1986), doktorat w Trier (1993), habilitację we Freiburgu (1997), był profesorem teologii pastoralnej i pedagogiki w Erfurcie (1993-2003). Prowadzi działalność duszpasterską w wielu parafiach oraz zajmuje się duszpasterstwem specjalistycznym. Autor licznych publikacji, ostatnio wydał Pastoral mit wiederverheirateten Geschiedenen, Regensburg 2015.

2 Oryginał: Ermutigung zur Seelsoge, „Herder Korrespondenz” 2016, nr 6, s. 13-14. 
Chociaż cała adhortacja jest bogata w cenne myśli i praktyczną mądrość życiową, to jednak z największym bodaj zainteresowaniem spotkał się jej ósmy rozdział dotyczący zasad obchodzenia się z takimi formami życia, „które nie są jeszcze lub już nie odpowiadają jego nauczaniu (tj. Kościoła - R.K.) o małżeństwie" (AL 292), przede wszystkim $\mathrm{z}$ chrześcijanami rozwiedzionymi, żyjącymi w nowych związkach.

Papież formułuje przy tym własne preferencje postępowania, oddzielając je od możliwych oczekiwań: „Biorąc pod uwagę niezliczoną różnorodność poszczególnych sytuacji (...), można zrozumieć, że nie należy oczekiwać od Synodu ani też od tej adhortacji nowych norm ogólnych typu kanonicznego, które można by stosować do wszystkich przypadków. Możliwa jest tylko nowa zachęta do odpowiedzialnego rozeznania osobistego i duszpasterskiego indywidualnych przypadków (...) (AL 300). Nie mamy tu więc do czynienia ze zmianą nauczania moralnego czy porządku prawnego, gdy idzie o związek seksualności z małżeństwem (AL 53), czy o odmowę dla związków jednopłciowych (AL 52), w przypadku nauki o dobrach małżeństwa: jedności, nierozerwalności, otwarości na dzieci (z wyraźnym wskazaniem na naukę Humanae vitae w AL 222, por. AL 80) czy wreszcie odnośnie do nierozerwalności małżeństwa w przypadku osób rozwiedzionych, żyjących w nowych związkach. Co więcej adhortacja wyklucza takie zmiany na płaszczyźnie norm powszechnych czy na płaszczyźnie prawa. Przedstawiając naukę Kościoła o małżeństwie, zwłaszcza w rozdziale trzecim, Franciszek pozostaje w granicach nauczania swoich poprzedników oraz Katechizmu Kościoła Katolickiego.

Franciszek: promotorem sakramentu pokuty

Wprowadzając swoje nauczanie w orbitę zainteresowania duszpasterstwa, uczynił, że to nauczanie stało się elementem duszpasterstwa, któremu w żaden sposób to nauczanie nie zagraża. Duszpasterstwo jest w ogóle hermeneutycznym kluczem Amoris laetitia. Franciszek wielki promotor sakramentu pokuty myśli po prostu radykalnie oforum internum, a więc o poradnictwie i prowadzeniu poszczególnej osoby w jej drodze ku Bogu i z Bogiem. Tutaj - jak wiadomo - ma 
dla niego istotne znaczenie discretio (rozeznanie) - owa najważniejsza cnota duszpasterza.

W tym sensie jest tylko prostą konsekwencją, że żaden z będących w użyciu modeli myślowych, obecnych w dyskusjach ostatnich dziesięcioleci, nie został poddany recepcji pod kątem ewentualnej zmiany czy przynajmniej „dostosowania” nauczania, gdy idzie o forum externum: żadne bowiem egzegetyczne refleksje co do słów Jezusa o rozwodzie, żadne rozważanie rzekomej akceptacji dla ponownych małżeństw po rozwodzie, jakie mieli wnieść ojcowie Kościoła, żadnej prawosławnej oikonomia, żadnej epikei i aequitas canonica (chociaż ta winna trafiać w jego intuicje!), żadnej próby nowego teologiczno-moralnego określenia warunków otrzymania sakramentów, a wreszcie żadnej próby rozwiązań kanonicznych. W sposób oczywisty dyskusja synodalna umocniła w papieżu Franciszku przekonanie, że owe alternatywne koncepcje teologiczne nie są niczym innym, jak tylko hipotezami, a tym samym - jako takie - nie powinny być rozstrzygane przez Urząd Nauczycielski Kościoła (AL 3).

Nawet pytanie o konieczną wiarę minimalną, jakiej się wymaga od narzeczonych do przyjęcia sakramentu małżeństwa, na którą wskazywał Benedykt XVI, nie zostało podjęte, a tym bardziej pogłębione. $\mathrm{W}$ takim podejściu widać konsekwencję papieża Francisza, który do końca prowadzi ów główny swój cel duszpasterski: poprzez naukę Kościoła i w niej w sposób nieuszczuplony należy urzeczywistniać miłosierdzie Boga, skierowane do każdego człowieka. To pytanie: „jak” jest decydujące. Czy aby przepowiadania Ewangelii o rodzinie „nie należy rozumieć jako 'jarzmo' nałożone na ludzi, ale jako 'dar' udzielony osobom złączonym w małżeństwie” (AL 62).

Tak zatem Amoris laetitia jest wielkim i ważnym dokumentem będącym zachętą do duszpasterstwa. Stanowi ważny impuls w przygotowaniach (się) do małżeństwa oraz w towarzyszeniu w małżeństwie; w żadnym razie nie wolno nam o nim zapomnieć przez najbliższe lata. „Tylko duszpasterstwo" - tej etykiety od dzisiaj nie wolno już stosować, jeśli zagadnienia duszpasterskie miałoby się traktować jako niegodne badań teologicznych. Duszpasterstwo jako miejsce teologiczne (locus theologicus) należy do najlepszych tradycji teologii jezuickiej. 
Wreszcie, kto zna choćby tylko pobieżnie wielkie kontrowersje, jakie były przyczyną zmian duszpasterskiej praxis wie, że wymaga się tutaj wielkiej precyzji. Nie jest ona wszakże domeną Amoris laetitia. Do argumentacji teologicznej wkradają się nieścisłości. Pojęcia, jak na przykład „ideał”, w odniesieniu do porządku małżeństwa są nieostre i sprzyjają błędnym interpretacjom (tutaj choćby: ideał jako docelowa zasada). Odniesienia są wyrwane $z$ kontekstu i używane przeciwko zamiarowi wypowiedzi, zaś konieczne rozróżnienia są ignorowane. Nie ogranicza to wielkich życzeń papieża, ale ujawnia, w jak małym stopniu teologia pastoralna jest w stanie odwoływać się do wypróbowanych kryteriów.

Oto niektóre dowody tej krytyki: analiza sytuacji, obecna przede wszystkim w rozdziale 2, w zasadzie nie wychodzi poza typową dla dokumentów Kościoła zwyczajność: w sposób nieostry i jakby dorywczo adhortacja zarysowuje pesymizm kulturowy, co wobec rozwiniętych badań nad rodziną jawi się jako niezrozumiały brak. Szczegółowo dokument posługuje się myślą św. Tomasza z Akwinu, ale $\mathrm{w}$ decydujących fragmentach nie jest to realizowane w sposób przekonywujący. I tak na przykład AL 301 odnosi się do sytuacji przymusowej związanej z zobowiązaniami zaciągniętymi w drugim małżeństwie, jednak zastosowane tu rozróżnienie Akwinaty między habitus a operatio cnót trzeba uznać za bardzo naciągane i mało przekonujące.

Trudno również pogodzić - wobec obowiązywalności normy powszechnej - nadawanie jakiejś wartości sytuacjom „nieprawidłowym” w AL 304 z tomaszową refleksją nad powszechnością prawa naturalnego (S. th. I-II qu 94 art. 4), ponieważ nierozerwalność małżeństwa, według Tomasza, należy właśnie do pierwszych i powszechnych zasad, a nie do kontyngentnych wniosków końcowych.

Oto wreszcie dochodzimy do dyskutowanej dziś kwestii dostępu do sakramentów osób rozwiedzionych, żyjących w nowych związkach. Chociaż papież akceptuje deklarację Papieskiej Rady ds. Interpretacji Tekstów Prawnych z 2000 r., która odwołuje się do kan. 915 Kodeksu Prawa Kanonicznego, jednak wypowiada tezę, że „negatywny osąd odnośnie do sytuacji obiektywnej nie oznacza orzeczenia 
o odpowiedzialności lub winie danej osoby" (AL 302). Skupiając jednak silną uwagę na duszpasterstwie oraz na forum internum, nie uwzględnia tego obiektywnego sprzeciwu. W ostrożnych napomknieniach odnośnie do możliwości przyjmowania sakramentów w przypisie 336 i 335 chodzi tylko o ocenę stanu sumienia (a więc kan. 916), nawet jeśli w ogóle rozważa się ten obiektywny, zewnętrznie widoczny sprzeciw. Tym samym przywołana została nauka tradycyjna (por. AL 301), na przykład zawarta w Familiaris consortio nr 84, dopuszczająca różnorodność sytuacji kiedy otrzymanie komunii remoto scandalo (por. AL 299) jest wszak możliwa. Zakłada to jednak w każdym przypadku poważny wysiłek uporządkowania własnego postępowania $\mathrm{z}$ zachowaniem respektu dla istniejącego węzła małżeńskiego („otwarte na nowe etapy rozwoju” jako kryterium, AL 303). Natomiast kto chciałby w tych mało istotnych przypisach dopatrywać się rewolucji w praktyce dopuszczania do Komunii św., musiałby ogłosić jakiś stan wyjątkowy, co zresztą prostodusznie przyznał sam papież w kilka dni po ogłoszeniu Amoris laetitia podczas konferencji prasowej w czasie swego lotu 16 kwietnia 2016 r., nie wspominając w ogóle o przypisie 351 .

Tym bardziej ważne pozostaje pytanie: czy duszpasterska orientacja, należny szacunek dla osoby ludzkiej i dicsretio w nieodwracalnym stanie tej osoby nie zmienia aby całej budowli nauki Kościoła? Czy nie mamy tu do czynienia ze swego rodzaju apelem do posługiwania się normami Kościoła w oparciu o osobistą ocenę i na mocy własnego sumienia? Czy ukierunkowanie na osobisty wzrost, na liczenie się z okolicznościmi, orientacja na przyjęcie i na towarzyszenie są ważniejsze niż obowiązujące powszechnie przykazania? W rzeczy samej, wielu odebrało Amoris laetitia jako sygnał i zachętę do urzeczywistniania katolickiej autonomii. Jednak nie to chroni adhortacja apostolska. Ową zamianę prawa stopniowania na stopniowanie prawa dokument zdecydowanie odrzuca (AL 295). Należy pamiętać, że discretio u św. Ignacego Loyoli odwołuje się do dobrego moralnie czy neutralnego przedmiotu wyboru (Ćwiczenia Duchowe, nr 170). Podnoszenie takiego zarzutu jest nieuprawnione; papież Franciszek daleki jest od schlebiania zawołaniom etyki sytuacyjnej. 
Amoris laetitia nie jest dokumentem wpisującym się w zasadę: Roma locuta, causa finita. Jest enuncjacją, która stanowi swego rodzaju zachętę do duszpasterstwa związków tylko akceptowalnych. Duszpasterstwa $\mathrm{z}$ sercem i rozsądkiem, mocno osadzonego w nauczaniu, ciepłego w udzielaniu i zdecydowanego w woli, aby „nikt z nich nie zginął” (por. J 17, 12).

tłum. Rafał J. Kupiszewski 